\title{
Review on Factors Affecting Technical Efficiency of Sorghum Production by Smallholder Farmers in Ethiopia
}

\author{
Alemayehu Keba ${ }^{1} \quad$ Dawit Milkias ${ }^{2}$ \\ 1.Ethiopian Institute of Agricultural Research, P.O.Box 2003, Addis Ababa, Ethiopia \\ 2. Ethiopian Institute of Agricultural Research, Ambo ARC, P.O.Box 37, Ambo, Ethiopia
}

\begin{abstract}
Sorghum is the most important cereal crop in the Ethiopia for home consumption and for marketing. Previous studies have indicated that farm production and productivity can possibly be raised by allocating more area for production, by developing and adopting of new technologies, and/or by utilizing the available resources more efficiently. Increasing productivity through enhanced sorghum production efficiency could be an important move towards food security. In Ethiopia sorghum production levels and rates have been increasing due to the development and dissemination of improved sorghum technologies. Despite these efforts by the government, smallholders' sorghum productivity has remained below potential. However, empirical studies conducted to estimate level of efficiencies and to identify its determining factors in sorghum production which would guide policy makers in their efforts are sparse. The main objective of this review is assessing the determinants of technical efficiency in sorghum production in Ethiopia. In these review factors like farm plot, age, education, and distance to all weather roads, livestock holding, participation in soil and water conservation activities, Knowledge about land policy, off-farm and investment on fertilizers, frequency of extension contact, share cropping credit access, crop diversification, and. The sorghum farms were being operated below level of technical efficiency. This implies that a large number of sorghum farms in the Ethiopia faced inefficiency problems.
\end{abstract}

Keywords: Sorghum, Technical efficiency, Determinants, Ethiopia

DOI: $10.7176 / \mathrm{JESD} / 11-9-07$

Publication date:May $31^{\text {st }} 2020$

\section{INTRODUCTION}

\subsection{Background of the review}

According to IFAD, (2013) result shows, agriculture is important for comprehensive development because it produces food as well as economic wealth for many of the world's lowliest people that allows for improved livelihoods through better health care, education, infrastructure improvements and greater investment in environmentally sound practices. For Sub Saharan Africa, growth generated by agriculture is eleven times more effective in reducing poverty than GDP growth in any other sectors. Rain fed, subsistence level, small land holding, and retrograde production technology characterize the agricultural sector in the Ethiopian economy (Hagos Weldegebriel, 2014).

Production and productivity can be boosted either through increased use of inputs and/or improvement in technology or by improving the efficiency of producers or firms, given fixed level of inputs and technology (Solomon-Bizuayehu-Wassie, 2014). Despite the tremendous development endeavors towards the MDGs in recent years, Ethiopia is among the poorest countries, MoFED (2012), on its interim report on poverty analysis, has shown the existence of rural-urban and regional disparity in poverty indices in Ethiopia. According to Hagos Weldegebriel (2014) show in his article On top of the regional disparity in poverty, there is also huge regional disparity in crop productivity as well. Maize, Sorghum and Teff are among the major cereals produced in the country.

Ethiopia's determined five-year growth and transformation plan, which was started in 2010, aims to double grain production by 2015. The major grain crops grown in the country are teff, wheat, maize, barley, sorghum, and millet. Out of the total grain production, cereals account for roughly 60 percent of rural employment and 80 percent of total cultivated land (Abu and Quintin, 2013) as cited by Solomon-Bizuayehu-Wassie(2014). Yield of cereals has been consistently well below world and even of least developing countries average yield, indicating poor productivity of the crops in the country. According to FAO (2011) as cited by Solomon-Bizuayehu-Wassie,(2014) the average cereal yield for the world and least developing countries were $37.08 \mathrm{qt} / \mathrm{ha}$ and $20.19 \mathrm{qt} / \mathrm{ha}$, respectively, however, the average cereal yield in Ethiopia was limited to $17.60 \mathrm{qt} / \mathrm{ha}$.

Even though agriculture stays the main stay of Ethiopian economy, level of agricultural productivity in general and crop productivity in particular is very low (Solomon-Bizuayehu-Wassie,2014). According to the result of Jema Haji and Bosena Tegegn, (2018), the major challenges facing most of developing countries such as Ethiopia is improving food security and stimulates underlying food system development. There is an everincreasing concern that it is becoming more and more difficult to achieve and sustain the needed increase in agricultural production based on intensification, because there are limited opportunities for area expansion. Hence, the solution to food problem would depend on measures, which help to increase yield through intensification. 
There have been few studies to determine the factor affecting technical efficiency of sorghum production of small holder farmers. The existing domain research and development efforts were so far seem to be unable to give the full empirical explanation as why small holders farmer in Ethiopia usually fail to give more about technical efficiency of sorghum production and way of improve production and productive to recommended them to the technology user farmers.

1.2 Objective of the Review: Review the factor affecting technical efficiency of sorghum production for smallholder farmers in Ethiopia.

\section{Literature Review}

In this chapter, concept of efficiency, approaches of efficiency measurement, models of efficiency and empirical studies on efficiency are discussed briefly.

\subsection{Definition and Concept}

Productivity and efficiency are both measures of production performance. However, there is slight difference between them. One can improve the state of technology by inventing new ploughs, pesticides, etc. This is commonly referred to as technological change and can be represented by an upward shift in the production frontier. Alternatively, one can improve farmers' education, extension service, etc. This in turn will improve production efficiency of farmers and will be represented by farmers operating more close to the existing frontier. Hence generally, productivity growth may be achieved through either technological progress or efficiency improvement (Coelli, 1995)

\subsection{Concept of Efficiency}

The simple and straight forward way of measuring efficiency of a farm could be yield per hectare. However, given output is a function of multiple inputs in the reality, this is very simplistic way of measurement in that it only considers a single input of production, land. The other technique is to use the conventional econometric analysis, which generally assumes that all producers always manage to optimize their production process. However, there are discrepancies between production amount and production values even if the enterprises have identical technological constraints (Burhan, Ceylan, and Hatice, 2009).

Thus production frontier characterizes the minimum input bundles required to produce a given level of output or the maximum possible level of production of output from a given level of inputs, commonly called technical efficiency. Even though there is some similarity between terms production efficiency and technical efficiency, however, they are not same. The simplest way to differentiate production and technical efficiency is to think of productive efficiency in terms of cost minimization by adjusting the mix of inputs, whereas technical efficiency is output maximization from a given mix of inputs (Palmer and Torgerson, 1999).

\subsection{Approaches of Measuring Efficiency}

Basically there are two approaches in measuring efficiency: input oriented and output oriented. The output oriented approach deals with the question "by how much output could be expanded from a given level of inputs?" Alternatively one could ask "by how much can input of quantities be proportionally reduced without changing the output quantity produced?" This is an input oriented measure of efficiency. However, both measures will coincide when the technology exhibits constant returns to scale, but are likely to vary otherwise (Coelli and Battese, 2005).

\subsection{Factor Affecting Technical Efficiency of Sorghum Production in Ethiopia}

According to Shumet (2011) survey result of the estimated stochastic frontier production function revealed that education of household heads, family literacy, family size, share cropping, credit access, crop diversification, and land fertility were found to have a positive and significant effect on efficiency. In contrast, Households' age, dependency ratio, livestock size, and off-farm activity affect efficiency negatively and significantly.

Education is believed to enhance the managerial and technical skills of households. According to Battese and Coelli (1995), education is hypothesized to increase the household's ability to utilize existing technologies and attain higher efficiency levels. Several studies indicated that education being associated with efficient management of production systems and hence higher efficiency levels and access to better education enables households to better manage their resources in order to sustain the environment and produce at optimum levels. This indicates that, education capacitating in human capital that enhances the productivity of households since they will be better able to allocate homemade and purchased inputs, select the appropriate quantities of purchased inputs and choose among available techniques like studies of (Ahmed et al., 2002; Wondimuetal., 2014).

According to the study of Jema Haji and Bosena Tegegn, (2018) survey the coefficient of family size in the technical inefficiency model is negative and significant at 5\% significance level. The result is similar to the expectation that those households having large family size are less inefficient than households having small family 
size, because; family labor is the main input in crop production. As the households have large family size, he/she would manage crop plots on time and may beable to use appropriate input combinations.

According to the study of Abdulai and Eberlin (2001) and Essa (2011). It is plausible that the household with more members can perform farming activities on time. Crop production is labor-intensive activity in Ethiopia. In this regard, the effect of household size on technical inefficiency cannot be over emphasized. In fact, the literature offers mixed results. On the one hand, people argue that an increase in the number of family members could decrease technical inefficiency if it results in increased labor allocated to crop production. The result is similar to the expectation that those households having large family size are less inefficient than households having small family size, because; family labor is the main input in crop production. As the households have large family size, he/she would manage crop plots on time and may be able to use appropriate input combinations. But these studies were inconsistent with the findings of Fekadu (2004), Mekdes (2011),Endalkachew (2012) and Hailemarim (2015). According to Jema Haji and Bosena Tegegn, (2018) survey result of the estimated stochastic frontier production function revealed that negative coefficients of education level, family size, off/nonfarm activities, extension contact and soil fertility status indicates that improvement in these factors results in a significant decrease in the level of technical inefficiency. Akin, positive coefficients of age, livestock holding and plots distance were found to increase households' technical inefficiency. According to Solomon-Bizuayehu-Wassie,(2014) survey result the inefficiency effect analysis shown that, age of the household head measured in years was found to be the determinant of technical inefficiency, of teff production and education was found to have negative and significant effect on major crops and wheat technical inefficiency (1\% significance level). Knowledge about land policy was found to have significant and negative effect on technical inefficiency of wheat production (1\% significance level). Similarly, participation in soil and water conservation activities was found to have negative and significant effect on technical inefficiency of major crops and wheat production. In this study frequency of extension contact was found to have unexpected and strange result; the more frequently the farmers meet extension workers the more it competes their time to do agricultural activities. The result of this study also confirmed as rich farmers are relatively less inefficient than poor once, in major crops production, and fertile plots of wheat are significantly less inefficient than infertile once. Similarly, flat teff and maize plots are more efficient than otherwise. The other plot specific variable that was found to have negative and significant effect on technical inefficiency of major crop production was adoption of improved seed. The last but not least, variable that explains variation in inefficiency was found to be livestock ownership.

\section{Conclusion and Recommendation}

\subsection{Conclusions}

The main objective dealt with in this review is to assess the factor affecting technical efficiency of sorghum smallholder production in Ethiopia. It is found that smallholder sorghum farmers are inefficient in resources used in the production of sorghum in the county. The review of factor affecting technical efficiency analysis show that the mean technical efficiencies were not operating at the possibility production frontier and there is a considerable potential to increase the productivity of sorghum with the present technologies and inputs available to smallholder sorghum producer. The identified determinants of technical efficiency in this review are farm plot, age, education, and distance to all weather roads, livestock holding, participation in soil and water conservation activities, Knowledge about land policy, off-farm and investment on fertilizers, frequency of extension contact, share cropping credit access, crop diversification, and land fertility.

\subsection{Recommendations}

The results of this review give information to policy makers on how to improve the technical efficiency and optimal use of resources in production of sorghum production in Ethiopia. The following recommendations have been drawn based on the review. It is important to give due attention for farmers education through establishing and strengthening informal education and short term trainings by using the available human and infrastructural facilities like extension agents and Farmers Training Centers (FTCs). Strengthening the existing farmers groups be it formal or informal and promoting the formation of other farmers groups. Policy initiatives that improve the livestock holding of farmers through improved livestock breeds, forage and nutrition and health services have to be put in place. Encouraging farmers to conserve the soil fertility improvement action by reducing the risks and keeping their land fertile.

\section{REFERENCE}

Abdulai, A. and Eberlin, R. 2001. Technical Efficiency during Economic Reform in Nicaragua: Evidence from Farm Household Survey Data. Economic Systems, 25:113-12

Ahmed, M. M., B. Gebremedhin, S. Benin and Ehui,S. 2002. Measurement and Source of Technical Efficiency of Land Tenure Contracts in Ethiopia. Environmental and Development Economics, 7:507-528.

Burhan, O., Ceylan, R.F. and Hatice, K. (2009) A Review of Literature on Productive Efficiency in Agricultural 
Production. Journal of Applied Scienes Research, 5(7): pp 796-801.

Coelli, T.J. (1995) Recent Development in Frontier Modelling and Efficiency Measurement. Australian Journal of Agricultural Economics, 39(---): pp 219-245.

Coelli, T.J. and Battese, G.E. (2005) An Introduction to Efficiency and Productivity Analysis. Kluwer Academic Publishers, Boston.

EndalkachewYehun. 2012. Technical Efficiency Analysis of Malt Barley Production: The Case of Smallholder Farmers in Debark Woreda, North Gondar Zone of the Amhara National Regional State. MSc Thesis, Haramaya University, Haramaya, Ethiopia

EssaChanie. 2011. Resource Use Efficiency of Smallholder Crop Production in the Central Highlands of Ethiopia. MSc Thesis, Egerton University, Egerton, Kenya.

Fekadu Gelaw. 2004. Analysis of Technical Efficiency of Wheat Production: A study in Machakel Woreda. MSc Thesis, Haramaya University, Haramaya, Ethiopia.

Hagos Weldegebriel, (2014). The Determinants of Technical Efficiency of Farmers in Teff, Maize and Sorghum Production: Empirical Evidence from Central Zone of Tigray Region. Ethiopian Journal of Economics Vol. XXIII No 2, October 2014

Hailemaraim Leggesse. 2015. Technical Efficiency in Tef Production: The Case of Bereh District,Oromia National Regional State. MSc Thesis, Haramaya University, Haramaya, Ethiopia

IFAD, (2013). African agricultural development: opportunities and challenges. Statement by IFAD President at the 6th Africa Agriculture Science Week and FARA General Assembly.

Jema Haji and Bosena Tegegn(2018).Technical Efficiency of Sorghum Production: the Case Of Smallholder Farmers in Konso District, Southern Ethiopia. Journal of Agricultural Economics, Extension and Rural Development: Vol. 6(7): pp, 772-793, October, 2018

MekdesAbera. 2011. Analysis of Technical Efficiency of Lentil (Lens Culinaris Medikus) Production: The Case of Gimbichu District, Eastern Shewa Zone of Oromia. MSc Thesis, Haramaya University, Haramaya, Ethiopia.

MoFED ,(2012). Ethiopia's Progress towards Eradicating Poverty: An Interim Report on Poverty Analysis Study in 2010/11. Addis Ababa. Ethiopia.

Palmer, S. and Torgerson, D.J. (1999) Economic notes: definitions of efficiency. [Internet]. 318(7191): pp 1136. Available from DIO: 10.1136/bmj.318.7191.1136. [PMC free article] Available from: http://www.ncbi.nlm.nih.gov/pmc/articles/PMC1115526/ [Accessed 26 November 2013].

Shumet, A. (2011) Analysis of technical efficiency of crop producing smallholder farmers in Tigray, Ethiopia. [Internet]. Munich Personal RePEc Archive (MPRA) Paper No. 40461. Available from: http://mpra.ub.unimuenchen.de/40461/ [Accessed 26 November 2013].

Solomon-Bizuayehu-Wassie,(2014).Technical Efficiency of Major crops In Ethiopia: Stochastic Frontier Model

Wondimu, T. and Hassen, B. 2014. Determinants of Technical Efficiency in Maize Production: The Case of Smallholder Farmers in Dhidhessa District of Illuababora Zone, Ethiopia. Journal of Economics and Sustainable Development, 5(15): 274-284.

Wondimu, T. and Hassen, B. 2014. Determinants of Technical Efficiency in Maize Production: The Case of Smallholder Farmers in Dhidhessa District of Illuababora Zone, Ethiopia. Journal of Economics and Sustainable Development, 5(15): 274-284.

Zalkuwi,J., Rakesh Singh, and Singh, O.P. 2014. Assessment of Technical Efficiency of Sorghum Production in Adamawa State, Nigeria.Asian Journal of Agriculture and Food Sciences, 2(6): 542-547. 